\title{
Growth Characteristics and Polyene Sensitivity of a Fatty Acid Auxotroph of Candida albicans
}

\author{
By T. Y. KOH, ${ }^{*}$ M. S. MARRIOTT, $†$ J. TAYLOR AND E. F. GALE \\ Sub-Department of Chemical Microbiology, Department of Biochemistry, \\ Tennis Court Road, Cambridge CB2 I $Q W$
}

(Received II March I977)

\begin{abstract}
A fatty acid auxotroph of Candida albicans 6406 , designated $A^{\prime} 44$ and originally isolated as an oleic acid requiring strain, has been shown to be a $\Delta^{9}$ desaturase mutant. Although lacking this step in fatty acid biosynthesis, it appears to retain the ability to desaturate monounsaturated fatty acids. The polyene sensitivity of the organism grown on different fatty acid supplements varied between $0.08 \pm 0.02$ and $\mathrm{I} \cdot 20 \pm 0.30 \mu \mathrm{g}$ amphotericin B methyl ester $\mathrm{ml}^{-1}$ for exponentially growing cells. In spite of this variation, the sterol composition remained fairly constant, the major differences lying in fatty acid composition. Stationaryphase cells were more resistant to amphotericin B methyl ester, although again this change was not associated with changes in sterol content. The organism was most resistant when grown in the presence of oleic or linoleic acid. Protoplasts derived from resistant organisms grown on these two fatty acids were also resistant, indicating that the structure of the cell wall was less important than that of the plasma membrane in determining polyene sensitivity under these conditions.
\end{abstract}

\section{INTRODUCTION}

Recent work indicates that the resistance of Candida albicans to polyene antibiotics during growth in batch culture increases as the cells enter the stationary phase (Gale, 1974). This phenotypic variation results from changes in the cell wall, since enzymic (protoplast formation) or chemical modification of the wall greatly reduces this resistance (Gale et al., 1975). The chemical procedures used to modify the polyene sensitivity would all be expected to interact with protein components of the wall. The changes in cell wall organization which render a cell resistant are as yet unknown.

Douglas et al. (1975) found that modifying the fatty acid content of the plasma membrane of Saccharomyces cerevisiae resulted in cells with walls which had various degrees of sensitivity to enzymic hydrolysis. These changes in susceptibility could be attributed to altered patterns of glucan and mannan (mannan-protein) biosynthesis. Marriott (1977) has also found that the plasma membrane-bound mannan synthetase of $C$. albicans is influenced by its lipid environment.

We have therefore investigated the relative roles of plasma membrane and cell wall structure in determining polyene sensitivity. For this we have studied the characteristics of polyene-induced $\mathrm{K}^{+}$release from a fatty acid auxotroph of $C$. albicans grown under a variety of conditions. This paper describes the results obtained and also presents information on the mechanism of fatty acid biosynthesis in this organism.

* Present address: Department of Biochemistry, Faculty of Medicine, University of Malaya, Kuala Lumpur, Malaysia.

$\dagger$ Present address: Fachbereich Biologie und Vorklinische Medizin, Universität Regensburg, 8400 Regensburg, West Germany. 


\section{METHODS}

Mutagenesis. The parent organism was Candida albicans 6406 , obtained from the Mycological Reference Laboratory, London School of Hygiene and Tropical Medicine, London. Cells from a culture growing exponentially in a synthetic yeast (SY) medium (Davies, 1953) were harvested and resuspended in fresh medium containing $200 \mu \mathrm{g} N$-methyl- $N^{\prime}$-nitro- $N$-nitrosoguanidine $\mathrm{ml}^{-1}$ (Koh, 1975). After 30 min incubation at $37{ }^{\circ} \mathrm{C}$, the cells were harvested, washed six times and resuspended in sterile water. Samples of different dilutions were plated out on a complex agar medium [containing $(\%, \mathrm{w} / \mathrm{v})$ : Difco yeast extract, $\mathrm{I}$; Difco Bactopeptone, I; glucose, 2; agar, 2] plus supplements [oleic acid, $0.2 \mathrm{mg} \mathrm{ml}^{-1}$; tergitol, $0 . \mathrm{I} \%$ (w/v)] to determine the number of survivors. Subsequently, master plates were prepared with approximately Ioo colonies per plate. Replicas from these master plates were transferred, using sterile velvet pads, to complex agar medium and synthetic agar medium [SY medium containing $2 \%(w / v)$ glucose and $2 \%(w / v)$ agar], with and without supplements. From the replica plates, a number of strains were selected which appeared to be fatty acid auxotrophs. Only one of these, designated $\mathrm{A}^{\prime} 44$, proved to be a strict auxotroph, although in a subsequent experiment a temperature-sensitive mutant was isolated.

Growth requirements. Although tergitol was originally used to solubilize the fatty acid in the growth medium, it was later found that the sodium salt would substitute satisfactorily. The abilities of several fatty acids, including dodecanoic $\left(\mathrm{C}_{12: 0}\right)$, tetradecanoic $\left(\mathrm{C}_{14: 0}\right)$, hexadecanoic $\left(\mathrm{C}_{16: 0}\right)$, octadecanoic $\left(\mathrm{C}_{18: 0}\right)$, $\Delta^{9}$-hexadecenoic $\left(C_{16: 1}\right), \Delta^{9}$-octadecenoic $\left(C_{18: 1}\right), \Delta^{9,12}$-octadecadienoic $\left(C_{18: 2}\right)$ and $\Delta^{9,12,15}$-octadecatrienoic $\left(\mathrm{C}_{18: 3}\right)$, to support the growth of strain $\mathrm{A}^{\prime} 44$ were tested at a range of concentrations.

Fatty acid and sterol composition. Cells were harvested after either $24 \mathrm{~h}$ (exponential phase) or $48 \mathrm{~h}$ (stationary phase) growth and lyophilized. The freeze-dried cells were extracted three times with chloroform/ methanol $(2: \mathrm{I}, \mathrm{v} / \mathrm{v})$, at least one extraction being carried out overnight (Marriott, 1975). The lipid extracts were washed according to the method of Folch, Lees \& Sloane-Stanley (1957). Samples of the lipid extract were transmethylated for gas-liquid chromatography using methanol/benzene/sulphuric acid (20: I0: I, by vol.) (Nichols \& Moorhouse, I969). Sterols were extracted, after saponification (Breivik \& Owades, I957), into heptane and analysed by gas-liquid chromatography without further modification. Fatty acid methyl esters were separated on a Pye series I04 gas chromatograph using a polyethylene glycol adipate column. For the separation of sterols, a JXR (polydimethylsiloxane) column was used (Vandenheuval \& Court, I968). Sterols were identified as described by Marriott (1975).

Polyene sensitivity. The sensitivity of cells grown on various fatty acid supplements to the methyl ester of amphotericin B (AME) was tested by measuring the release of potassium ions as described previously (Gale, 1974). The sensitivity of protoplasts derived from these cells was also tested. The standard release concentration (s.r.c.), defined as that concentration of antibiotic which would elicit a release rate of $\mathrm{I}$ nmol $\mathrm{K}^{+} \min ^{-1}$ within $8 \mathrm{~min}$ (Gale, 1974), was used as a comparative measure of polyene sensitivity.

Materials. All materials used were analytical reagent grade where available. $C_{12: 0}, C_{14: 0}, C_{16: 0}, C_{16: I}$ and $\mathrm{C}_{18: 0}$ fatty acids were obtained from Calbiochem. $\mathrm{C}_{18: 1}, \mathrm{C}_{18: 2}$ and $\mathrm{C}_{18: 3}$ fatty acids were from Sigma. The purity of each fatty acid was tested by gas-liquid chromatography of its methyl ester, with the following results: $\mathrm{C}_{16: 1}$ contained $99 \% \mathrm{C}_{16: 1}$ and a trace of $\mathrm{C}_{18: 1} ; \mathrm{C}_{18: 1}$ contained $6 \% \mathrm{C}_{16: 0,10 \%} \% \mathrm{C}_{16: 1}, 76 \% \mathrm{C}_{18: 1}$ and $4 \% \mathrm{C}_{18: 2} ; \mathrm{C}_{18: 2}$ contained $2 \% \mathrm{C}_{16: 1}, 8 \% \mathrm{C}_{18: 1}$ and $89 \% \mathrm{C}_{18: 2} ; \mathrm{C}_{18: 3}$ contained $5 \% \mathrm{C}_{18: 1}, 19 \% \mathrm{C}_{18: 2}$ and $76 \% \mathrm{C}_{18: 3}$.

AME was the kind gift of Professor C. P. Schaffner of Rutgers University, U.S.A.

\section{RESULTS}

\section{Growth requirements}

The auxotrophic strain of Candida albicans designated A'44 was originally isolated as an oleic acid $\left(\mathrm{C}_{18: 1}\right)$ requiring mutant. The ability of this strain to grow on other fatty acids is shown in Table $\mathrm{I}$. Whilst other unsaturated fatty acids could substitute for oleic acid, saturated ones could not. The mean generation times of the mutant grown on the various fatty acids were considerably longer than that of the parent strain growing in unsupplemented SY medium (approximately $90 \mathrm{~min}$ ).

Strain $\mathrm{A}^{\prime} 44$, when grown in the presence of $5 \%(\mathrm{v} / \mathrm{v})$ horse serum, produced germ tubes. This is a standard diagnostic test for Candida albicans. 
Table I. Growth characteristics of Candida albicans strain A'44 in SY medium supplemented with various fatty acids, present as their sodium salts

$\begin{array}{lcc}\begin{array}{c}\text { Fatty acid } \\ \text { supplement }\left(\mathrm{mg} \mathrm{ml}^{-1}\right)\end{array} & \begin{array}{c}\text { Mean } \\ \text { generation } \\ \text { time (min) }\end{array} & \begin{array}{c}\text { Growth } \\ \text { yield } \\ \left(\mathrm{mg} \mathrm{ml}^{-1}\right)\end{array} \\ \mathrm{C}_{12: 0}, \mathrm{C}_{14: 0}(\text { each } \cdot 1) & - & - \\ \left.\mathrm{C}_{18: 0}, \mathrm{C}_{18: 0} \text { (each } 0 \cdot 1\right) & - & - \\ \mathrm{C}_{16: 1}(0 \cdot 1) & 190 \pm 10 & - \\ \mathrm{C}_{18: 1}(0 \cdot 2) & 220 \pm 15 & 2 \cdot 10 \\ (0 \cdot 1) & 220 \pm 10 & 2 \cdot 00 \\ (0 \cdot 05) & 220 \pm 15 & 1 \cdot 60 \\ (0 \cdot 025) & 220 \pm 10 & 0 \cdot 69 \\ C_{18: 2}(0 \cdot 1) & 270 \pm 20 & 1 \cdot 40 \\ C_{18: 3}(0 \cdot 1) & 290 \pm 20 & 2 \cdot 00\end{array}$

Table 2. Percentage fatty acid and lipid composition of whole cells of Candida albicans strain A'44 grown with various fatty acid supplements

Strain $\mathrm{A}^{\prime} 44$ was grown with fatty acids at $0.1 \mathrm{mg} \mathrm{ml}^{-1}$ unless otherwise stated. The results are the mean of at least three determinations and standard deviations are given. Results for both exponential- and stationary-phase cells were within these limits. The fatty acid composition of the parent strain 6406 is included for comparison.

Strain $\mathrm{A}^{\prime} 44$, grown with:

\begin{tabular}{|c|c|c|c|c|c|c|}
\hline \multirow[b]{2}{*}{ Fatty acid } & \multirow{2}{*}{$\begin{array}{c}\text { Strain } \\
6406\end{array}$} & \\
\hline & & $C_{16: 1}$ & $C_{18: 1}$ & $C_{18: 1} *$ & $C_{18: 2}$ & $\mathrm{C}_{18: 3}$ \\
\hline$C_{14: 0}$ & 2 & - & - & $1 \cdot 2 \pm 0 \cdot 2$ & - & $0.6 \pm 0.2$ \\
\hline $\mathrm{C}_{15: 0}$ & I & $0.8 \pm 0.1$ & $3.3 \pm 0.3$ & $4 \cdot 8 \pm 0.4$ & $2 \cdot 6 \pm 0.3$ & $1.6 \pm 0.2$ \\
\hline$C_{16: 0}$ & 15 & $16 \cdot 5 \pm I \cdot 3$ & $18 \cdot 7 \pm 2 \cdot I$ & $36 \cdot 8 \pm 1 \cdot 4$ & $39.3 \pm 0.7$ & $3 \mathrm{I} \cdot 6 \pm 3 \cdot 3$ \\
\hline $\mathrm{C}_{16: 1}$ & 20 & $59.4 \pm 0.4$ & $6.9 \pm 0.6$ & - & $3.6 \pm 0.4$ & - \\
\hline $\mathrm{C}_{18: 0}$ & 2 & $16.1 \pm 0.7$ & $\mathrm{I} 5 \cdot 4 \pm \mathrm{I} \cdot 4$ & $32 \cdot 6 \pm 2 \cdot I$ & $33 \cdot 8 \pm 0.9$ & $27 \cdot 5 \pm 2 \cdot 6$ \\
\hline$C_{18: 1}$ & $3 I$ & - & $32.7 \pm 3.5$ & $6.3 \pm 0.2$ & - & = \\
\hline$C_{18: 2}$ & $23 \dagger$ & - & $22 \cdot 4 \pm 2 \cdot 2$ & $\mathrm{I} 5 \cdot 5 \pm \mathrm{I} \cdot 3$ & $14 \cdot 2 \pm I \cdot 6$ & $9 \cdot 0 \pm I \cdot I$ \\
\hline $\mathrm{C}_{18: 3}$ & 4 & - & $0.9 \pm 0.1$ & $2.6 \pm 0.4$ & $6 \cdot 2 \pm 0.8$ & $30 \cdot 0 \pm 2 \cdot 9$ \\
\hline $\begin{array}{l}\text { Lipid } \\
\text { content (\%) }\end{array}$ & - & $4 \cdot 6 \pm I \cdot 2$ & $4 \cdot 8 \pm \mathrm{I} \cdot \mathrm{I}$ & $3 \cdot I \pm 0.5$ & $4 \cdot 3 \pm 0 \cdot 6$ & $3 \cdot 7 \pm 0.9$ \\
\hline
\end{tabular}

* Present at $0.025 \mathrm{mg} \mathrm{ml}^{-1}$.

$\dagger$ Resolved into two components of approximately equal proportions. These may represent $\Delta^{9,12}$ and $\Delta^{9,15}$ isomers of $\mathrm{C}_{18: 2}$.

\section{Fatty acid and sterol composition}

Table 2 gives the fatty acid composition of whole-cell lipid extracts, after growth on various unsaturated fatty acids. The fatty acid composition of the parent strain grown in SY medium has been included for comparison. When strain $\mathrm{A}^{\prime} 44$ was grown on $\mathrm{C}_{18}$ fatty acids, extracts contained little or no $\mathrm{C}_{16: 1}$. The small amounts detected could have been due to impurities in the fatty acids used. However, when grown with $\mathrm{C}_{16: 1}$ as supplement, this was the major fatty acid and no unsaturated $C_{18}$ fatty acids were present. $C_{16: 1}$ was also found in significant amounts in lipid extracts from the parent organism. As the fatty acids at $0.1 \mathrm{mg} \mathrm{ml}^{-1}$ were not limiting growth, the fatty acid compositions of exponential- and stationary-phase cells were not significantly different.

The sterol composition of strain $\mathrm{A}^{\prime} 44$ grown in SY medium with different fatty acid supplements is given in Table 3. Small but significant differences were observed between exponential- and stationary-phase cells. However, the overall patterns of sterol composition were essentially similar under the various growth conditions. The sterols present were also the major sterols found in the parent organism. 
Table 3. Percentage sterol composition of whole cells of Candida albicans 6406 grown in $S Y$ medium and the fatty acid auxotroph $\mathrm{A}^{\prime} 44$ grown with various fatty acid supplements

Fatty acids were present at $0.1 \mathrm{mg} \mathrm{ml}^{-1}$ unless otherwise stated. Cells were harvested after $24 \mathrm{~h}$ (exponential phase) or $48 \mathrm{~h}$ (stationary phase). The results are the mean of three determinations; maximum variations were within $\pm 10 \%$ of these values.

\begin{tabular}{|c|c|c|c|c|c|c|c|c|c|c|}
\hline \multirow[b]{3}{*}{ Sterol } & \multicolumn{5}{|c|}{ Exponential phase } & \multicolumn{5}{|c|}{ Stationary phase } \\
\hline & \multirow{2}{*}{$\begin{array}{c}\text { Strain } \\
6406\end{array}$} & \multicolumn{4}{|c|}{ Strain A'44, grown with: } & \multirow{2}{*}{$\begin{array}{c}\text { Strain } \\
6406\end{array}$} & \multicolumn{4}{|c|}{ Strain $A^{\prime} 44$, grown with: } \\
\hline & & $\mathrm{C}_{16: 1}$ & $\mathrm{C}_{18: 1}$ & $\mathrm{C}_{18: 2}$ & $\mathrm{C}_{18: 3}$ & & $\mathrm{C}_{16: 1}$ & $\mathrm{C}_{18: 1} *$ & $\mathrm{C}_{18: 2}$ & $\mathrm{C}_{18: 3}$ \\
\hline Total $(\%$ dry wt) & 0.66 & 0.75 & 0.59 & 0.58 & 0.69 & 0.90 & $\mathrm{I} \cdot 17$ & 0.74 & $0.7 I$ & 0.96 \\
\hline Zymosterol & 15 & $4 I$ & 34 & 26 & 26 & 29 & 36 & 34 & 35 & 33 \\
\hline Ergosterol & 66 & 35 & 45 & 36 & 38 & 36 & 30 & 44 & 27 & 49 \\
\hline 24,28-Dehydroergosterol & 4 & 9 & $\begin{array}{r}75 \\
9\end{array}$ & 16 & 14 & 13 & 12 & 9 & I4 & 7 \\
\hline 4-Methylzymosterol & 5 & 5 & 6 & I 2 & 9 & 6 & 10 & 7 & IO & 6 \\
\hline $4,4^{\prime}$-Dimethylzymosterol & 2 & IO & 6 & 10 & 13 & 15 & 12 & 6 & 14 & 5 \\
\hline
\end{tabular}

Table 4. Polyene sensitivity of Candida albicans strain A'44 grown with various fatty acid supplements

The fatty acids were present in the growth medium at $0.1 \mathrm{mg} \mathrm{ml}^{-1}$ unless otherwise stated. Results are expressed as s.r.c. of AME (see Methods) under the different growth conditions. They are the mean of at least three determinations and standard deviations are given. Results of Gale et al. (1975) for the parent strain $\mathbf{6 4 0 6}$ are included for comparison.

\begin{tabular}{|c|c|c|c|c|}
\hline \multirow[b]{2}{*}{$\begin{array}{l}\text { Fatty acid } \\
\text { supplement }\end{array}$} & \multicolumn{4}{|c|}{ Polyene sensitivity (s.r.c. in $\mu \mathrm{g} \mathrm{AME} \mathrm{ml}^{-1}$ ) } \\
\hline & $\begin{array}{l}\text { Exponential- } \\
\text { phase cells }\end{array}$ & $\begin{array}{l}\text { Protoplasts from } \\
\text { exponential- } \\
\text { phase cells }\end{array}$ & $\begin{array}{l}\text { Stationary- } \\
\text { phase cells }\end{array}$ & $\begin{array}{c}\text { Protoplasts from } \\
\text { stationary- } \\
\text { phase cells }\end{array}$ \\
\hline $\mathrm{C}_{16: 1}$ & $0.08 \pm 0.02$ & $\longrightarrow$ & $0.65 \pm 0.15$ & $0.90 \pm 0.30$ \\
\hline $\mathrm{C}_{18: 1}$ & $1 \cdot 20 \pm 0.30$ & $0.80 \pm 0.30$ & $2 \cdot 50 \pm 0.20$ & - \\
\hline $\mathrm{C}_{18: 1} *$ & - & 二 & $0.70 \pm 0.20$ & $0.90 \pm 0.40$ \\
\hline $\mathrm{C}_{18: 2}$ & $0.75 \pm 0.25$ & $0.85 \pm 0.15$ & $3 \cdot 80 \pm 1 \cdot 00$ & $2 \cdot 80 \pm 0 \cdot 30$ \\
\hline $\mathrm{C}_{18: 3}$ & $0.08 \pm 0.02$ & - & $1 \cdot 60 \pm 0.30$ & $0.70 \pm 0.30$ \\
\hline Strain 6406 & 0.12 & 0.07 & 5.00 & 0.15 \\
\hline
\end{tabular}

\section{Polyene sensitivity}

Values of the s.r.c. of AME for strain A'44 grown in the presence of various unsaturated fatty acids are given in Table 4 . This table also compares the sensitivity of exponential- and stationary-phase cells and protoplasts derived from them. When grown in the presence of $\mathrm{C}_{16: 1}$ and $\mathrm{C}_{18: 3}$, exponential-phase cells were as sensitive as the parent strain and, hence, protoplasts from these cells were not tested. Under all growth conditions, an increase in resistance to $\mathrm{AME}$-induced $\mathrm{K}^{+}$leakage was observed as the cells entered stationary phase.

\section{DISCUSSION}

The fatty acid auxotroph Candida albicans $\mathrm{A}^{\prime} 44$ has a growth requirement for an unsaturated fatty acid. Although not tested rigorously, it clearly resembles the $\Delta^{9}$ desaturase mutants of Saccharomyces cerevisiae isolated by Resnick \& Mortimer (1966). The formation of $\Delta^{9}$ unsaturated fatty acids from the saturated acid was first shown in $S$. cerevisiae by Bloomfield \& Block (I960). Keith, Resnick \& Haley (I969) identified a number of independent genetic loci in this organism, which control this desaturation step. However, little 
information is available on the enzymic mechanism of further desaturation ( $\Delta^{12}$ and $\left.\Delta^{15}\right)$ in yeasts. The work of Wisnieski, Keith \& Resnick (1970) suggests there was little or no conversion of the added unsaturated fatty acid into other fatty acids.

Unfortunately, the fatty acids used in our study were not $100 \%$ pure. Nevertheless, a number of valid observations can be made. Firstly, when grown on palmitoleic acid $\left(\mathrm{C}_{16: 1}\right)$ no longer chain unsaturated fatty acids were found, indicating that conversion of palmitoleic to oleic $\left(C_{18: 1}\right)$ acid does not occur. Secondly, although the oleic acid used as a growth supplement was contaminated with linoleic acid $\left(\mathrm{C}_{18: 2}\right)$ this was too low to account for the amount of linoleic acid found in these cells, particularly at the lower concentration. Thirdly, the samples of oleic and linoleic acids did not contain any linolenic acid $\left(C_{18: 3}\right)$, yet this fatty acid was found in extracts from cells grown with these supplements. These last two observations indicate that, in $C$. albicans, a different set of enzymes from those involved in the initial $\Delta^{9}$ desaturation step control the conversion of oleic acid to linoleic and linolenic acids. The resolution of the $C_{18: 2}$ peak into components by gas-liquid chromatography, probably representing $\Delta^{9,12}$ and $\Delta^{9,15}$ isomers of $C_{18: 2}$, suggests that the conversion of oleic to linolenic acid may occur via two intermediates.

In terms of polyene sensitivity, exponential-phase cells of strain $A^{\prime} 44$ grown in the presence of oleic or linoleic acid were significantly more resistant than the parent strain grown in unsupplemented SY medium. Protoplasts derived from these cells were, within experimental error, equally resistant. With all four unsaturated fatty acids, stationary-phase cells were more resistant than the corresponding exponential-phase cells. This resistance could again be largely attributed to the plasma membrane rather than the cell wall, since protoplasts derived from these cells were almost equally resistant.

Some variation in sterol composition was observed when strain $\mathrm{A}^{\prime} 44$ was grown in the presence of different unsaturated fatty acids. However, these variations were not sufficient to account for the large variations in polyene sensitivity of the corresponding cells or protoplasts. The variation in sensitivity thus appears to be due to the differing fatty acid compositions, although no direct correlation can be made. HsuChen \& Feingold (1973) and Archer (1976) have suggested that sterol-phospholipid interaction, rather than the presence of sterol per se, is important in determining the binding of polyenes to membranes. It would appear that our results reflect these observations; however, confirmation of this would require a detailed chemical analysis of the plasma membrane from resistant cells.

This work was supported by a grant from the Medical Research Council.

\section{REFERENCES}

Archer, D. B. (1976). Effect of the lipid composition of Mycoplasma mycoides subspecies capri and phosphatidylcholine vesicles upon the action of polyene antibiotics. Biochimica et biophysica acta 436, 68-76.

Bloomfield, D. K. \& Block, K. (1960). The formation of $\Delta^{9}$ unsaturated fatty acids. Journal of Biological Chemistry 235, 337-345.

Breivik, O. N. \& Owades, J. L. (1957). A semimicromethod for determining the percentages of ergosterol and 24,28 dehydroergosterol. Journal of Agricultural and Food Chemistry 5, 360-363.

DAVIES, R. (1953). Enzyme formation in Saccharomyces fragilis. I. Invertase and raffinase. Biochemical Journal 55, 484-497.

Douglas, L. J., Atkinson, D. M., Hossack, J. A. \& Rose, A. H. (1975). A possible role for lipid unsaturation in the biosynthesis of wall polymers in Saccharomyces cerevisiae. In Abstracts of the Fourth International Symposium on Yeast and Other Protoplasts, p. $7 \mathrm{I}$.
Folch, J., Lees, M. \& Sloane-Stanley, G. H. (1957). A simple method for the isolation and purification of total lipids from animal tissues. Journal of Biological Chemistry 226, 497-509.

Gale, E. F. (I974). The release of potassium ions from Candida albicans in the presence of polyene antibiotics. Journal of General Microbiology 80, $45 \mathrm{I}-465$.

Gale, E. F., Johnson, A. M., Kerridge, D. \& $\mathrm{KoH}, \mathrm{T}$. Y. (1975). Factors affecting the changes in amphotericin sensitivity of Candida albicans during growth. Journal of General Microbiology 87 , 20-36.

HsuChen, C. C. \& Feingold, D. S. (i973). Polyene antibiotic action on lecithin liposomes: effect of cholesterol and fatty acyl chains. Biochemical and Biophysical Research Communications 51,972-978.

Keith, A. D., Resnick, M. A. \& Haley, A. B. (I969). Fatty acid desaturase mutants of Saccharomyces cerevisiae. Journal of Bacteriology 98, 4I5-420. 
KoH, T. Y. (1975). The isolation of obligate osmophilic mutants of the yeast Saccharomyces rouxii. Journal of General Microbiology 88, I84-I 88.

MARRIOTT, M. S. (I975). Isolation and chemical characterization of plasma membranes from the yeast and mycelial forms of Candida albicans. Journal of General Microbiology 85, 1 I5-1 32.

MARRIOTT, M.S. (1977). Mannan-protein location and biosynthesis in plasma membranes from the yeast form of Candida albicans. Journal of General Microbiology (in the Press).

Nichols, B. W. \& Moorhouse, R. (I969). The separation, structure and metabolism of monogalactosyl diglyceride species in Chlorella vulgaris. Lipids 4, $31 \mathrm{I}-316$.
Resnick, M.A. \& Mortimer, R. K. (I966). Unsaturated fatty acid mutants of Saccharomyces cerevisiae. Journal of Bacteriology 92, 597-600.

Vandenheuval, F. A. \& Court, S. A. (1968). Reference high-efficiency nonpolar packed columns for the gas-liquid chromatography of nanogram amounts of steroids. I. Retention time data. Journal of Chromatography 38, 439-459.

WisNieski, B. J., KeITH, A. D. \& Resnick, M. A. (1970). Double bond requirement in a fatty acid desaturase mutant of Saccharomyces cerevisiae. Journal of Bacteriology ror, I60-165. 